\title{
Dormancy overcoming, temperatures and substrates on germination of Mimosa tenuiflora Willd seeds
}

\section{Superação de dormência, temperaturas e substratos na germinação de sementes de Mimosa tenuiflora Willd}

\author{
Clarisse Pereira Benedito ${ }^{1 *}$; Maria Clarete Cardoso Ribeiro ${ }^{2}$; Salvador Barros \\ Torres $^{1}$; Isaías Porfírio Guimarães ${ }^{3}$; Kássya Jemima Borges de Oliveira ${ }^{4}$
}

\begin{abstract}
Mimosa tenuiflora Willd., popularly known as jurema-preta, is an arboreal species of great importance for the brazilian Northeast due to its uses as a medicinal plant and in the restoration of degraded soils. No information is available in the Rules for Seed Analysis and the Instructions for Seed Analysis of Forest Species regarding ideal conditions for of this species. Thus, this study aimed at evaluating the influence of pre-germination treatments, in addition to verifying the germination performance at different temperatures and in different substrates. In both experiments, four replicates of 25 seeds were used for each treatment. In experiment I, seeds were submitted to the following methods for overcoming dormancy: witness - Intact seeds (T1) immersion in water at $100^{\circ} \mathrm{C}$ for 1 (T2), 2 (T3), 3 (T4), 4 (T5), 5 (T6) and 6 min (T7), immersion in concentrated sulfuric acid for 1 (T8), 4 (T9), 7 (T10), 10 (T11) and 13 $\min$ (T12), scarification on sandpaper $\mathrm{n}^{\circ} 80$ (T13) and lopping in the region opposite the micropyle (T14). In experiment II, seed germination was evaluated in four types of substrates: between sand, paper on, paper roll and between vermiculite and at six different temperatures: $20,25,30,35,40{ }^{\circ} \mathrm{C}$ and alternating between 20 and $30^{\circ} \mathrm{C}$. Immersion in hot water for 1, 2, 3, 4, 5 and $6 \mathrm{~min}$, sulfuric acid treatment for 10 and $13 \mathrm{~min}$, sand paper and lopping were the most appropriate treatments to overcome seed dormancy. The seed germination of $M$. Tenuiflora should be carried out at $25^{\circ} \mathrm{C}$ on paper roll substrate.
\end{abstract}

Key words: Jurema-preta. Seed germination. Caatinga. Seed analysis.

\section{Resumo}

Mimosa tenuiflora Willd. conhecida popularmente como jurema-preta é uma espécie arbórea de grande importância para o Nordeste brasileiro pela sua multiplicidade de usos, como na medicina popular, recuperação de solos degradados e fixação de nitrogênio. Ainda não há informações disponíveis nas Regras para Análise de Sementes e nas Instruções para Análise de Sementes de Espécies Florestais com relação às condições ideais para condução do teste de germinação desta espécie. Dessa forma, objetivou-se avaliar a influência da aplicação de tratamentos pré-germinativos, além de verificar o desempenho da germinação em diferentes temperaturas e substratos. Em ambos os experimentos foram utilizados quatro repetições de 25 sementes para cada tratamento. No experimento I, as sementes foram submetidas aos seguintes métodos para superação de dormência: testemunha - sementes intactas (T1), imersão em água a $100{ }^{\circ} \mathrm{C}$ por um (T2), dois (T3), três (T4), quatro (T5), cinco (T6) e seis minutos (T7), imersão em ácido sulfúrico concentrado por um (T8), quatro (T9), sete (T10), dez (T11) e treze minutos

\footnotetext{
1 Profs., Universidade Federal Rural do Semi-Árido, UFERSA, Mossoró, RN, Brasil. E-mail: clarisse@ufersa.edu.br; sbtorres@ ufersa.edu.br

2 Prof ${ }^{a}$, Universidade da Integração Internacional da Lusofonia Afro-Brasileira, UNILAB, Redenção, CE, Brasil. E-mail: clarete@ unilab.edu.br

3 Dr. em Fitotecnia, UFERSA, Mossoró, RN, Brasil. E-mail: isaiasporfirio@yahoo.com.br

4 Mestre em Fitotecnia, UFERSA, Mossoró, RN, Brasil. E-mail: kassyajemima@hotmail.com

* Author for correspondence
} 
(T12), escarificação em lixa ${ }^{\circ} 80$ (T13) e desponte na região oposta a micrópila (T14). No experimento II, a germinação das sementes foi avaliada em quatro tipos de substratos: entre areia, sobre papel, rolo de papel e entre vermiculita e em seis temperaturas: $20^{\circ} \mathrm{C}, 25^{\circ} \mathrm{C}, 30^{\circ} \mathrm{C}, 35^{\circ} \mathrm{C}, 40^{\circ} \mathrm{C}$ e alternada 20 $30^{\circ} \mathrm{C}$. A imersão em água quente por 1, 2, 3, 4, 5 e 6 minutos, ácido sulfúrico por 10 e 13 minutos, lixa e desponte são os tratamentos mais indicados para a superação de dormência da espécie. O teste de germinação de sementes de $M$. tenuiflora pode ser conduzido a $25^{\circ} \mathrm{C}$, no substrato rolo de papel.

Palavras-chave: Jurema-preta. Germinação de sementes. Caatinga. Análise de sementes.

\section{Introduction}

Mimosa tenuiflora Willd. is a native Fabaceae species of Caatinga, popularly known as juremapreta, calumbi or jurema. It reaches a height of five to seven metres, has sparse spines, an erect or slightly inclined stem, dark brown bark, sometimes greyish, rough, chipped lengthwise, with dark red bark. Its seeds are small (3-4 mm), oval, flattened and have a light brown colour. It can be found throughout the Northeast region, in the states of Piauí, Ceará, Rio Grande do Norte, Paraíba, Pernambuco, Alagoas, Sergipe and Bahia. It has potential as a regenerator of eroded soils and a nitrogen fixer, favouring the emergence of other, more demanding native plants, such as Myracrodruon urundeuva Allem., Handroanthus impetiginous (Mart. Ex. DC) Mattos, Amburana cearenses (A. C. Smith), Adenanthera colubrina (Vell.), Ziziphus joazeiro Mart., Combretum leprosum Mart. (MAIA, 2004). Furthermore, it is used for medicinal purposes against various diseases (SOUZA et al., 2008).

Analysis of forest seeds is essential in scientific research, where knowledge of the main processes involved in native species seed germination is crucial for the preservation and multiplication of endangered species as well as other species in reforestation programs (SMIDERLE; SOUSA, 2003).

Commonly, the concept of dormancy only reflects the absence of viable seed germination under unfavourable environmental conditions. However, this might only be one factor impeding germination. Absence or excess of water, suboptimal temperatures or even the absence of light are some of environmental factors affecting germination processes. Additionally, seed intrinsic properties are the second and most important factors inhibiting germination, which is represented by embryo characteristics and other structures including endosperm, tegument or even action of fruits (VIVIAN et al., 2008).

The effectiveness of pre-germination treatments to overcome seed dormancy mainly depends on the degree of species dormancy and the time of exposure to the treatment. Several studies show that these elements directly influence dormancy in seeds of several species, such as Bowdichia virgilioides (SMIDERLE; SCHWENGBER, 2011), Acacia mangium (SMIDERLE et al., 2005), Piptadenia moniliformis Benth. (BENEDITO et al., 2008; AZERÊDO et al., 2010), Caesalpinia pulcherrima (OLIVEIRA et al., 2010), Bowdichia virgilioides (ALBUQUERQUE et al., 2007), Parkia panurensise, Parkia multijuga and Parkia velutina (MELO et al., 2011).

The main methods used for overcoming physical dormancy are: soaking in water, chemical scarification with acids and mechanical scarification using sandpaper (BRASIL, 2009). Such methods ensure tegument rupture, facilitating the entry of water and oxygen, resulting in an early germination process (BRASIL, 2009).

The germination test is still considered the main parameter to evaluate the physiological quality of seeds. Seeding rates, value comparison between different lots and commercialization are determined by this test (MARTINS et al., 2008). The ideal methodology for conducting this test for the most cultivated species can be found in Rules for Seed Analysis (BRASIL, 2009) or Instructions 
for Analysis of Forest Seeds (BRASIL, 2013). However, few native species of Caatinga are considered in these manuals. In this sense, Lima et al. (2011) obtained better results in seed germination of Caesalpinia pyramidalis Tul. at 20-30 and $20-35^{\circ} \mathrm{C}$ temperatures with sand and vermiculite substrates. For P. moniliformis Benth. seeds, $25{ }^{\circ} \mathrm{C}$ with the substrates between paper, between sand and between vermiculite were the most suitable condition for conducting germination tests (AZERÊDO et al., 2011). For seeds of Amburana cearensis (Allemao) A. C. Smith, a temperature of $35^{\circ} \mathrm{C}$ temperature was most suitable for the germination test, irrespective of the substrate (GUEDES et al., 2010).

Given the importance of forestry and the lack of information to assist in the management of dormancy and conduction of germination tests for M. tenuiflora seeds, this study aimed at evaluating the influence of pre-germination treatments, temperature and substrate on germination tests for this species.

\section{Material and Methods}

Mature fruits of twenty $M$. tenuiflora mother plants were collected, of which ten were located at the Universidade Federal Rural do Semi-Árido - UFERSA ( $\left.5^{\circ} 12^{\prime} 51^{\prime} \mathrm{S} ; 37^{\circ} 18^{\prime} 44,7^{\prime} \mathrm{W}\right)$ and ten nearby at the Instituto Federal do Rio Grande do Norte-IFRN ( $\left.5^{\circ} 12 ` 58,8^{\prime} \mathrm{S} ; 37^{\circ} 18^{`} 51,65^{`} \mathrm{~W}\right)$, both located in the municipality of Mossoró - RN. After collection, we removed broken and cracked seeds and stored the remaining seeds in glass bottles in a cold chamber $\left(15^{\circ} \mathrm{C} \pm 60 \% \mathrm{RH}\right)$ until experiments.

Initially, seed humidity level was determined by the greenhouse method at $105 \pm 3{ }^{\circ} \mathrm{C}$ for 24 hours (BRASIL, 2009), with two replicates of 25 seeds, whose value was $9.9 \%$. Later, the soaking curve was determined in order to verify whether dormancy was caused by tegument impermeability. For this, two samples of 25 intact seeds were weighted before contact with moistened paper and then disposed between two sheets of blotting paper which was pre-moistened with an amount of water equal to 2.5 times the weight of dry paper. The intervals of weightings were 2, 4, 6, 8, 24, 48, 72 and 96 soaking hours. As intact seeds had slow water absorption, indicating tegumentary dormancy, a new soaking curve with seeds treated with hot water at $100{ }^{\circ} \mathrm{C}$ for four minutes was prepared. This treatment was chosen from results in pre-preliminary tests, with three-phase behaviour.

Thus, the following treatments were used: witness - intact seeds (T1), immersion in water at $100{ }^{\circ} \mathrm{C}$ for 1 (T2), 2 (T3), 3 (T4), 4 (T5), 5 (T6) and $6 \mathrm{~min}$ (T7), immersion in concentrated sulfuric acid for 1 (T8), 4 (T9), 7 (T10), 10 (T11) and $13 \mathrm{~min}$ (T12), scarification on sandpaper $n^{\circ} .80$ (T13) and lopping in the region opposite the micropyle (T14). The experiment was conducted in a greenhouse with sowing in plastic trays $(1 \mathrm{~cm}$ depth) in sandy substrate previously washed, autoclaved and divided into four replicates of 25 seeds.

In the treatment with sulfuric acid (P.A 98\%), seeds were placed in a beaker, covered with acid and frequently shaken with a glass rod. After each test period, contents were put into a plastic sieve with seeds rinsed in running water to eliminate acid waste and placed to dry on paper towels at room temperature.

Within the treatment with hot water, seeds were placed in a beaker and immersed in water. After each period, the disposal of water was similar to that in the acid sulfuric treatment.

For mechanical scarification, seeds were manually rubbed with sandpaper No 80 until visible tegument weathering. For seed lopping, to made a small cut into the opposite site of the micropyle, using scissors.

The following variables were evaluated: emergence - number of normal emerged seedlings from three to 21 days after sowing, after which seed emergence was stabilised; the results were expressed as percentage; emergency speed index - daily count of normal seedlings during 21 days, 
and the index according to Maguire (1962) was performed; mean emergence time - calculated using the formula proposed by Labouriau (1983).

The experimental design was completely randomized and data was submitted to analysis of variance; means were compared by Tukey's test at $5 \%$ probability. In order to homogenise variances, percentage data were transformed to arc sine function $(\mathrm{X} / 100)^{1 / 2}$.

In the second experiment, germination in paper (sterilised at $105{ }^{\circ} \mathrm{C}$ for two hours), vermiculite and sand (sterilised at $120{ }^{\circ} \mathrm{C}$ for two hours) was evaluated. In addition, we disinfected seeds using $0.5 \%$ sodium hypochlorite for $2 \mathrm{~min}$ and subsequently washed them with distilled water.

The four tested substrates were sand, paper, paper roll and vermiculite, using six temperatures, 20, 25 , 30,35 and $40{ }^{\circ} \mathrm{C}$, and alternating $20-30{ }^{\circ} \mathrm{C}$. We used $197 \mathrm{~g}$ of sand per plastic box ("gerbox" type, $11 \mathrm{x}$ $11 \times 3 \mathrm{~cm}$ ), moistened with $37 \mathrm{~mL}$ of distilled water (60\% of field capacity). For sowing "on paper", two sheets of blotting paper were used, arranged in a "gerbox" and moistened with a quantity of water equal to 2.5 times the dry weight of the paper. For germination on paper rolls, we used three sheets of "germitest" also moistened with a quantity of water equal to 2.5 times the dry weight of the paper. Vermiculite of medium grain size was moistened with an amount of water equal to 2.0 times its dry weight (BRASIL, 2013).

Germination tests were evaluated daily for ten days when stabilization of the results was verified. The characteristics evaluated were: germination a total of 100 seeds per treatment was used, divided into four sub-samples of 25 seeds, using as criteria the normal seedling count reported in the Rules for Seed Analysis (BRASIL, 2009); first germination count: the percentage of seeds that had germinated by the 5th day; germination speed index - daily counts of normal seedlings for ten days and calculated index according to the formula proposed by Maguire (1962); mean germination time calculated according to the formula proposed by Labouriau (1983); percentage of hard and dead seeds - as hard seeds, considered those that did not absorb water. As dead seeds, it was considered those which did not germinate, were mollified or attacked by microorganisms (BRASIL, 2009).

The experimental design was completely randomized in a $6 \times 4$ factorial scheme with six temperatures: $20,25,30,35,40$ and $20-30{ }^{\circ} \mathrm{C}$, alternating between four substrates (sand, paper, paper roll and vermiculite), with four replicates of 25 seeds, totalling 24 treatments. Data were submitted to analysis of variance and means were compared by Tukey's test at 5\% probability.

\section{Results and Discussion}

The results for soaking curves of intact and scarified seeds of $M$. tenuiflora showed radicle protrusion in $60 \%$ of the scarified seeds after 72 hours of soaking, while in the same period, only $8 \%$ of intact seeds had germinated (Figure 1). For the remaining intact seeds, it was performed weighing up to 144 hours; however, seedlings remained at a constant weight without germination. Germination of some intact seeds can be explained with a possible difference in the intensity of dormancy, since according to Marcos-Filho (2015), seeds are released from the mother plant with different degrees of dormancy, a phenomenon known as heteroblasty or polymorphism; thus, some may germinate without pre-germination treatments. 
Figure 1. Soaking curve of Mimosa tenuiflora Willd intact seeds scarified with hot water $\left(100^{\circ} \mathrm{C}\right)$ for four minutes.

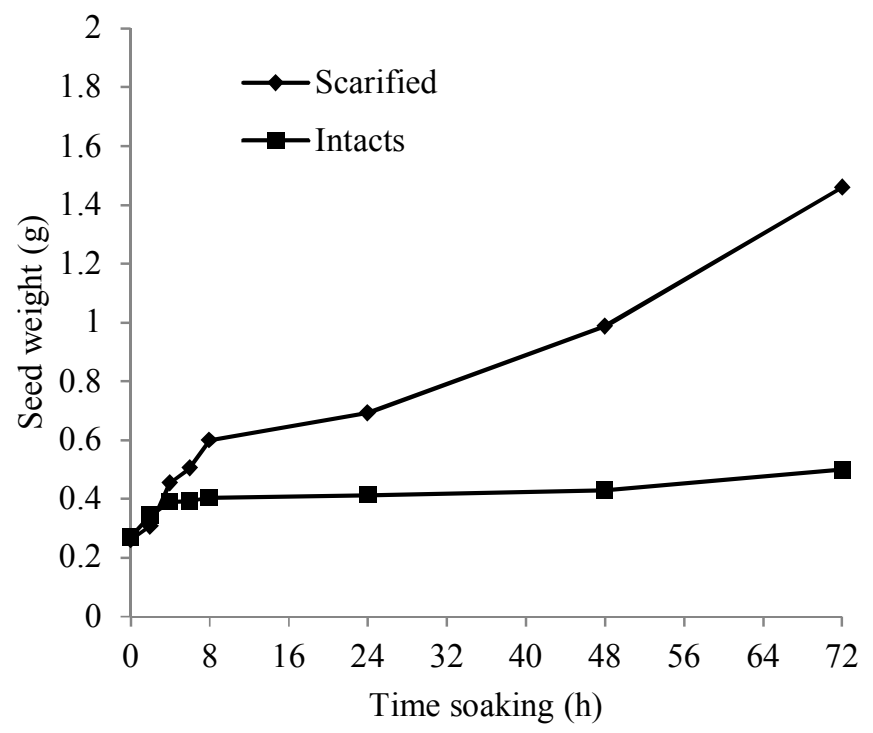

For seedling emergence, it was found that the witness treatment resulted in an average of only $5 \%$ germination, which was not statistically different from the sulfuric acid treatment for $1 \mathrm{~min}$. In contrast, we found highest values of seedling emergence in the hot water treatments (T2 to T7) and the sulfuric acid treatments $\mathrm{T} 11$ and $\mathrm{T} 12$. Germination rates were equally high for treatments with sandpaper $\mathrm{n}^{\circ} .80$ (T13) and lopping (T14), with no statistical difference between treatments (Figure 2A).

The use of hot water, in addition to being a low cost method and without risk of toxicity, as compared to the sulfuric acid treatment, is also more practical than using sandpaper or lopping, especially for small seeds such as those of $M$. tenuiflora. Satisfactory results with the use of hot water immersion were also obtained for Caesalpinia pyramidalis Tul.) (ALVES et al., 2007), Acacia mangium Willd. (SMIDERLE et al., 2005), Leucaena diversifolia Schlecht. (SOUZA et al., 2007). However, this method was not effective in overcoming dormancy in seeds of Albizia lebbeck (L.) Benth.) (DUTRA; MEDEIROS FILHO, 2009), Adenanthera pavonina L. (SILVA et al., 2009), Schizolobium amazonicum (Huber) Ducke) (SHIMIZU et al., 2011) and Mimosa caesalpiniifolia Benth. (PASSOS et al., 2007), which is probably due to insufficient exposure time or elevated temperatures, negatively affecting embryo viability.

Regarding emergence speed index, the best treatments were lopping, hot water immersion for $1,2,3,4,5$ and 6 min as well as treatment with sulfuric acid for $10 \mathrm{~min}$ and sandpaper, with no considerable differences between treatments, while the other treatments provided inferior results (Figure 2B). Regarding mean emergence time, both sandpaper and seed lopping favoured the reduction of this variable (Figure 2C).

Alves et al. (2007) achieved higher germination speed and lower mean time with mechanical scarification using sandpaper was used for $C$. pyaramidalis Tull. seeds. Similar results to this study were also obtained by Nascimento et al. (2009) for seeds of Parkia platycephala Benth.), with scarification with sandpaper and immersion in sulfuric acid as the most effective treatments. For Ormosia arborea (Vell.) Harms., mechanical and chemical scarification for 10, 20 and $30 \mathrm{~min}$ reduced dormancy and significantly increased seed germination speed (LOPES et al., 2004). Alexandre et al. (2009) obtained better results for overcoming dormancy in seeds of Enterolobium contortisiliquum (Vell.) Morong. by using mechanical scarification, achieving lower mean times of emergence and increased emergence speed index. 
Figure 2. Seedling emergence (A), emergency speed index (B) and average time of emergency (C) of Mimosa tenuiflora Willd. seeds submitted to fourteen treatments for overcoming dormancy.
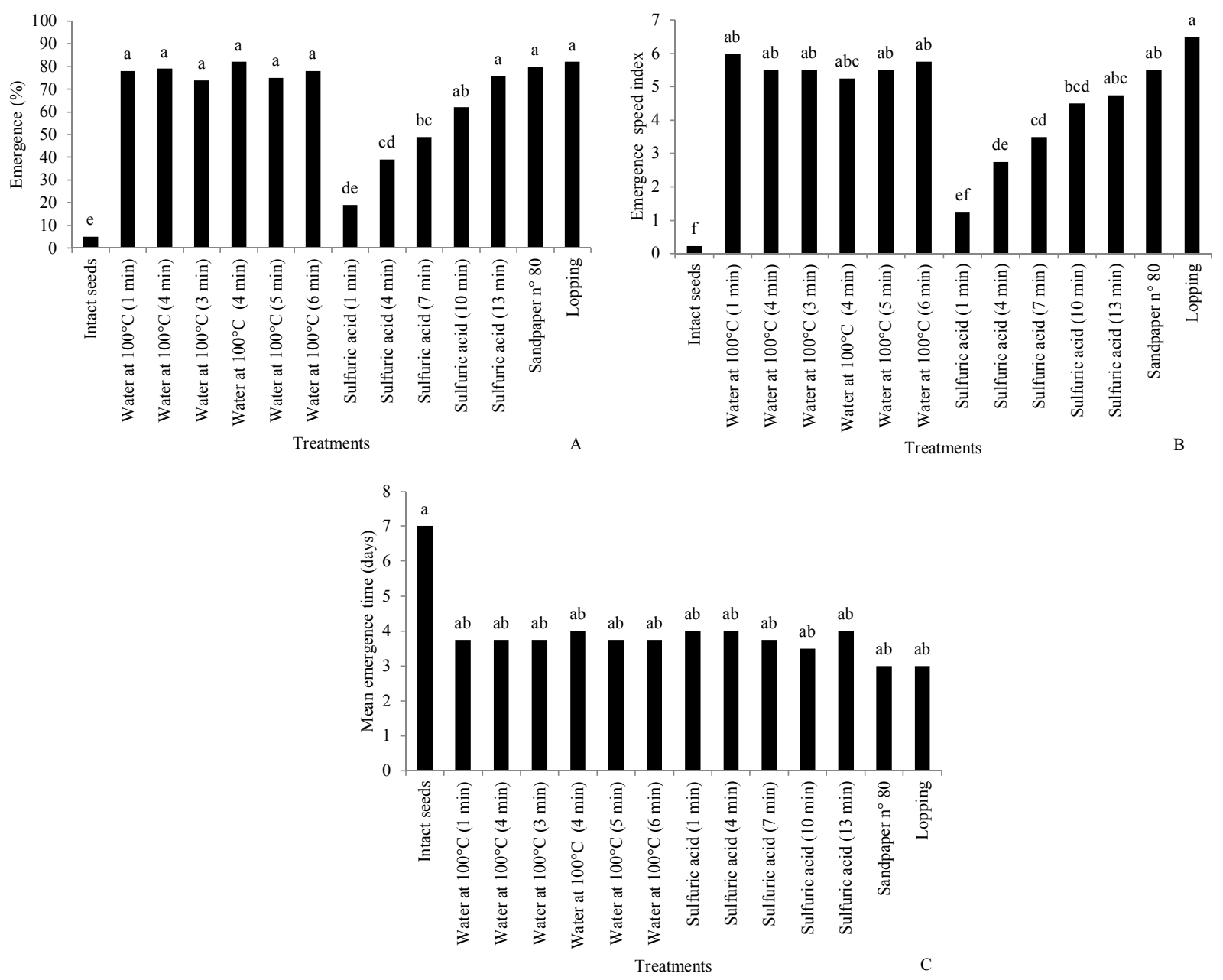

In terms of temperatures and substrates for germination of $M$. tenuiflora seeds (Table 1), it was found that for the first count, the paper roll provided higher values, except at $40{ }^{\circ} \mathrm{C}$, whereas highest average values of germination were found at $25{ }^{\circ} \mathrm{C}$, regardless of the substrate. The alternating temperature of $20-30{ }^{\circ} \mathrm{C}$ resulted in better performance on paper roll and paper, with no considerable difference between substrates. It found that the temperature of $40{ }^{\circ} \mathrm{C}$ negatively impacted germination of $M$. tenuiflora seeds, with germination rates reaching zero for the substrates paper and vermiculite. For M. caesalpiniifolia seeds Alves et al. (2002) also found that applying a temperature of $25^{\circ} \mathrm{C}$ and using paper as substrate resulted in highest values of first germination count.

Regarding the percentage of germination, it was found that the paper roll was statistically superior to other substrates, whereas sand and vermiculite substrates resulted in lower germination rates, irrespective of temperature. In the roll paper substrate, all temperatures provided similar germination rates, except $40{ }^{\circ} \mathrm{C}$. At temperatures of 25 and $30{ }^{\circ} \mathrm{C}$, there were no statistical differences between substrates (Table 1). 
Table 1. First germination count, germination percentage and mean germination time of Mimosa tenuiflora Willd. seeds on different substrates and at varying temperatures.

\begin{tabular}{|c|c|c|c|c|c|}
\hline \multicolumn{6}{|c|}{ Substrates } \\
\hline \multirow{2}{*}{$\begin{array}{c}\text { Temperatures } \\
\left({ }^{\circ} \mathrm{C}\right)\end{array}$} & \multicolumn{4}{|c|}{ First germination count $(\%)$} & \multirow[b]{2}{*}{ Averages } \\
\hline & Between sand & Paper roll & On paper & Between vermiculite & \\
\hline 20 & $28 \mathrm{Bc}$ & $92 \mathrm{Aa}$ & $52 \mathrm{Bb}$ & $23 \mathrm{Bc}$ & $49 \mathrm{C}$ \\
\hline 25 & $78 \mathrm{Aa}$ & $92 \mathrm{Aa}$ & $87 \mathrm{Aa}$ & $77 \mathrm{Aa}$ & $83 \mathrm{~A}$ \\
\hline 30 & $65 \mathrm{Ab}$ & $86 \mathrm{Aa}$ & $75 \mathrm{Aab}$ & $63 \mathrm{Ab}$ & $72 \mathrm{~B}$ \\
\hline 35 & $27 \mathrm{Bb}$ & $86 \mathrm{Aa}$ & $38 \mathrm{Bb}$ & $3 \mathrm{BCc}$ & $38 \mathrm{D}$ \\
\hline 40 & $1 \mathrm{Ca}$ & $3 \mathrm{Ba}$ & $0 \mathrm{Ca}$ & $0 \mathrm{Ca}$ & $1 \mathrm{E}$ \\
\hline $20-30$ & $36 \mathrm{Bc}$ & $80 \mathrm{Aab}$ & $93 \mathrm{Aa}$ & $68 \mathrm{Ab}$ & $69 \mathrm{~B}$ \\
\hline Averages & $39 \mathrm{c}$ & $73 \mathrm{a}$ & $57 \mathrm{~b}$ & $39 \mathrm{c}$ & \\
\hline \multicolumn{6}{|c|}{ Germination (\%) } \\
\hline 20 & $79 \mathrm{Aab}$ & $95 \mathrm{Aa}$ & $73 \mathrm{BCb}$ & $72 \mathrm{Bb}$ & $80 \mathrm{~B}$ \\
\hline 25 & $87 \mathrm{Aa}$ & $93 \mathrm{Aa}$ & $95 \mathrm{Aa}$ & $93 \mathrm{Aa}$ & $92 \mathrm{~A}$ \\
\hline 30 & $83 \mathrm{Aa}$ & $87 \mathrm{Aa}$ & $79 \mathrm{ABCa}$ & $80 \mathrm{Aba}$ & $82 \mathrm{AB}$ \\
\hline 35 & $41 \mathrm{Bbc}$ & $94 \mathrm{Aa}$ & $59 \mathrm{Cb}$ & $26 \mathrm{Cc}$ & $55 \mathrm{C}$ \\
\hline 40 & $3 \mathrm{Cb}$ & $57 \mathrm{Ba}$ & $2 \mathrm{Db}$ & $2 \mathrm{Db}$ & $15 \mathrm{D}$ \\
\hline 20-30 & $53 \mathrm{Bb}$ & $88 \mathrm{Aa}$ & $93 \mathrm{Aba}$ & $90 \mathrm{ABa}$ & $81 \mathrm{~B}$ \\
\hline Averages & $57 \mathrm{c}$ & $86 \mathrm{a}$ & $67 \mathrm{~b}$ & $60 \mathrm{bc}$ & \\
\hline \multicolumn{6}{|c|}{ Mean germination time (days) } \\
\hline 20 & $5.51 \mathrm{ABab}$ & $3.12 \mathrm{Ac}$ & $4.13 \mathrm{Bbc}$ & $5.86 \mathrm{Aa}$ & $4.66 \mathrm{~A}$ \\
\hline 25 & $3.43 \mathrm{Ca}$ & $3.07 \mathrm{Aa}$ & $3.18 \mathrm{Ba}$ & $3.68 \mathrm{Ba}$ & $3.34 \mathrm{~B}$ \\
\hline 30 & $3.88 \mathrm{BCa}$ & $3.08 \mathrm{Aa}$ & $3.21 \mathrm{Ba}$ & $3.84 \mathrm{Ba}$ & $3.50 \mathrm{~B}$ \\
\hline 35 & $4.30 \mathrm{BCc}$ & $3.34 \mathrm{Ac}$ & $5.87 \mathrm{Ab}$ & 7.39 Aa & $5.22 \mathrm{~A}$ \\
\hline 40 & $6.66 \mathrm{Aa}$ & $6.79 \mathrm{Aa}$ & $0 \mathrm{Cb}$ & $7.0 \mathrm{Aa}$ & $5.11 \mathrm{~A}$ \\
\hline $20-30$ & 4.26 $\mathrm{BCa}$ & $3.36 \mathrm{Aa}$ & $3 \mathrm{Ba}$ & $3.97 \mathrm{Ba}$ & $3.65 \mathrm{~B}$ \\
\hline Averages & $4.67 \mathrm{~b}$ & $3.79 \mathrm{~b}$ & $3.23 \mathrm{~b}$ & $5.29 \mathrm{a}$ & \\
\hline
\end{tabular}

Average followed by the same letter, capital in the column and small in the line, did not differ by Tukey test at $5 \%$ probability.

Similar germination results were also obtained by Scalon et al. (2007) for seeds of Dimorphandra mollis. The authors compared constant $\left(25^{\circ} \mathrm{C}\right)$ and alternating temperatures $\left(20-30{ }^{\circ} \mathrm{C}\right)$ and obtained higher values for percentage and germination speed at a constant temperature. The most suitable conditions for germination of Dalbergia nigra Fr. Allem. seeds were observed at temperatures of 25 and 20-30 ${ }^{\circ} \mathrm{C}$, for paper roll and vermiculite substrates (ANDRADE et al., 2006). In our experiment, the most suitable temperature range for germination was between 25 and $30^{\circ} \mathrm{C}$, because at $20-30{ }^{\circ} \mathrm{C}$ alternating regime, seeds were exposed to a lower temperature $\left(20^{\circ} \mathrm{C}\right)$ for a longer period of time $(16$ hours). In a similar study, Melo and Barbedo (2007) concluded that a temperature of $25^{\circ} \mathrm{C}$ and the roll paper substrate represented he most appropriate conditions for germination of Caesalpinia echinata Lam. seeds.

The temperature of $40{ }^{\circ} \mathrm{C}$ negatively impacted germination in all substrates used, except for roll of paper, where germination reached $57 \%$ of seeds (Table 1). According to Carvalho and Nakagawa (2012), temperatures above the optimum accelerate germination, however, disrupting it, the total number of seeds that can complete it decreases. In contrast, temperatures below the optimum tend to reduce germination speed, in some cases leading to a reduction of total germination.

Regardless of the substrate, average germination time was shorter for M. tenuiflora seeds at 25,30 and 20-30 ${ }^{\circ} \mathrm{C}$, whereas for the substrates sand, paper roll 
and paper, germination did not differ significantly between treatments, independent of temperature (Table 1). Analysed separately, a temperature of $25{ }^{\circ} \mathrm{C}$ resulted in a germination speed index which was statistically higher than for the other tested temperatures, since the paper roll substrate resulted in significantly higher germination speed indices compared to the use of other substrates, independent of temperature. At temperatures of 25 and $30^{\circ} \mathrm{C}$ and temperatures alternating between 20 and $30{ }^{\circ} \mathrm{C}$, it was observed higher values of germination speed index for most substrates. At all temperatures, using paper roll as a substrate resulted in higher similar or statistically similar values compared to other substrates (Table 2).

Table 2. Germination speed index, percentage of hard and dead seeds of Mimosa tenuiflora Willd. on different substrates and at varying temperatures.

\begin{tabular}{|c|c|c|c|c|c|}
\hline \multicolumn{6}{|c|}{ Substrates } \\
\hline \multirow{2}{*}{ Temperatures $\left({ }^{\circ} \mathrm{C}\right)$} & \multicolumn{4}{|c|}{ Germination speed index } & \multirow[b]{2}{*}{ Averages } \\
\hline & Between sand & Paper roll & On paper & Between vermiculite & \\
\hline 20 & $4.12 \mathrm{Bb}$ & $7.72 \mathrm{Aa}$ & $5.07 \mathrm{BCb}$ & $3.60 \mathrm{Bb}$ & $5.13 \mathrm{C}$ \\
\hline 25 & $6.81 \mathrm{Aa}$ & 7.69Aa & 7.46Aa & $6.98 \mathrm{Aa}$ & $7.25 \mathrm{~A}$ \\
\hline 30 & $6.05 \mathrm{Aa}$ & 7.17Aa & $6.40 \mathrm{ABa}$ & $5.85 \mathrm{Aa}$ & $6.36 \mathrm{~B}$ \\
\hline 35 & $2.74 \mathrm{Bbc}$ & 7.45Aa & $3.92 \mathrm{Cb}$ & $1.50 \mathrm{Cc}$ & $3.90 \mathrm{D}$ \\
\hline 40 & $0.15 \mathrm{Cb}$ & $2.03 \mathrm{Ba}$ & $0.0 \mathrm{Db}$ & $0.12 \mathrm{Cb}$ & $0.57 \mathrm{E}$ \\
\hline $20-30$ & $3.60 \mathrm{Bb}$ & 6.94Aa & 7.74Aa & $6.44 \mathrm{Aa}$ & $6.18 \mathrm{~B}$ \\
\hline Averages & $3.9 \mathrm{c}$ & $6.5 \mathrm{a}$ & $5.12 b$ & $4.1 \mathrm{~b}$ & \\
\hline \multicolumn{6}{|c|}{ Hard seeds (\%) } \\
\hline 20 & $15.0 \mathrm{ABa}$ & $3.0 \mathrm{Ab}$ & $18.0 \mathrm{Aa}$ & $19.0 \mathrm{ABa}$ & $13.7 \mathrm{~A}$ \\
\hline 25 & 7.0Ba & $2.0 \mathrm{Aa}$ & $2.0 \mathrm{Ca}$ & $3.0 \mathrm{Ca}$ & $3.5 \mathrm{~B}$ \\
\hline 30 & $13.0 \mathrm{ABa}$ & 8.0Aa & $15.0 \mathrm{ABa}$ & $6.0 \mathrm{Ca}$ & $10.5 \mathrm{~A}$ \\
\hline 35 & $22.0 \mathrm{Aa}$ & $0.0 \mathrm{Ab}$ & $7.0 \mathrm{BCb}$ & $22.0 \mathrm{Aa}$ & $12.7 \mathrm{~A}$ \\
\hline 40 & $15.0 \mathrm{ABab}$ & $9.0 \mathrm{Ab}$ & $21.0 \mathrm{Aa}$ & 13.0ABCab & $14.5 \mathrm{~A}$ \\
\hline $20-30$ & $21.0 \mathrm{Aa}$ & $7.0 \mathrm{Ab}$ & $3.0 \mathrm{Cb}$ & $9.0 \mathrm{BCb}$ & $10.0 \mathrm{~A}$ \\
\hline Averages & $15.5 \mathrm{a}$ & $4.83 \mathrm{c}$ & $11.0 \mathrm{~b}$ & $12.0 \mathrm{ab}$ & \\
\hline \multicolumn{6}{|c|}{ Dead seeds $(\%)$} \\
\hline 20 & $6 \mathrm{Ca}$ & $2 \mathrm{Ba}$ & $9 \mathrm{Ca}$ & $9 \mathrm{Ca}$ & $6.5 \mathrm{C}$ \\
\hline 25 & $6 \mathrm{Ca}$ & $6 \mathrm{Ba}$ & $3 \mathrm{Ca}$ & $4 \mathrm{Ca}$ & $4.7 \mathrm{C}$ \\
\hline 30 & $4 \mathrm{Ca}$ & $1 \mathrm{Ba}$ & $6 \mathrm{Ca}$ & $1 \mathrm{Ca}$ & $3 \mathrm{C}$ \\
\hline 35 & $37 \mathrm{Bb}$ & $6 \mathrm{Bc}$ & $34 \mathrm{Bb}$ & $51 \mathrm{Ba}$ & $32 \mathrm{~B}$ \\
\hline 40 & $81 \mathrm{Aa}$ & $34 \mathrm{Ab}$ & $80 \mathrm{Aa}$ & $84 \mathrm{Aa}$ & $69.7 \mathrm{~A}$ \\
\hline $20-30$ & $25 \mathrm{Ba}$ & $5 \mathrm{Bb}$ & $4 \mathrm{Cb}$ & $1 \mathrm{Cb}$ & $8.7 \mathrm{C}$ \\
\hline Averages & $26.5 \mathrm{a}$ & $9 \mathrm{~b}$ & $23 \mathrm{a}$ & $25 \mathrm{a}$ & \\
\hline
\end{tabular}

Average followed by the same letter, capital in the column and small in the line, did not differ by Tukey test at $5 \%$ probability.

These results partly agree with those obtained by Figliolia et al. (2009), who evaluated the germination of Anadenanthera colubrina seeds at different temperatures and found higher percentages and germination speed values for constant temperatures of 20 and $25^{\circ} \mathrm{C}$. Similarly, Azerêdo et al. (2011) evaluated different substrates and temperatures for germination of $P$. moniliformis seeds and found that at $25^{\circ} \mathrm{C}$ and with paper roll as substrate, higher germination speed index was obtained.

Lower percentages of hard seeds were observed at $25{ }^{\circ} \mathrm{C}$, regardless of the substrate. In addition, 
we found that the paper roll substrate, independent of temperature, resulted in lower numbers of hard seeds. For a temperature of $25{ }^{\circ} \mathrm{C}$, no statistical differences between the substrates were detected; for paper roll as substrate, temperatures had no significant impact on germination. In all substrates, a temperature of $40{ }^{\circ} \mathrm{C}$ resulted in a higher percentage of dead seeds (Table 2). High temperatures favour seed deterioration (BELLO et al., 2008), in seeds of Amburana ocreana (Ducke) A. C. Sm. at the same temperature.

\section{Conclusions}

Immersion in hot water for 1, 2, 3, 4, 5 and 6 minutes, sulfuric acid treatment for 10 and 13 minutes, sandpaper and lopping are the most suitable treatments for overcoming dormancy in seeds of M. tenuiflora.

In addition, seed germination of $M$. Tenuiflora should be carried out at $25^{\circ} \mathrm{C}$ using on paper rolls as substrate.

\section{References}

ALBUQUERQUE, K. S.; GUIMARÃES, R. M.; ALMEIDA, I. F.; CLEMENTE, A. C. Métodos para superação de dormência em sementes de sucupirapreta (Bowdichia virgilioides KUNTH.). Ciência e Agrotecnologia, Lavras, v. 31, n. 6, p. 1716-1721, 2007.

ALEXANDRE, R. S.; GONÇALVES, F. G.; ROCHA, A. P.; ARRUDA, M. P.; LEMES, E. Q. Tratamentos físicos e químicos na superação de dormência em sementes de Enterolobium contortisiliquum (Vell.) Morong. Revista Brasileira de Ciências Agrárias, Recife, v. 4, n. 2, p. 156159, 2009.

ALVES, E. U.; CARDOSO, E. A.; BRUNO, R. L. A.; ALVES, A. U.; ALVES, A. U.; GALINDO, E. A. BRAGA JÚNIOR, J. M. Superação da dormência em sementes de Caesalpinia pyramidalis Tul. Revista Árvore, Viçosa, MG, v. 31, n. 3, p. 405-415, 2007.

ALVES, E. U.; PAUlA, R. C.; OLIVEIRA, A. P.; BRUNO, R. L. A.; DINIZ, A. A. Germinação de sementes de Mimosa Caesalpiniaefolia Benth. em diferentes substratos e temperaturas. Revista Brasileira de Sementes, Londrina, v. 24, n. 1, p. 169-178, 2002.
ANDRADE, A. C. S.; PEREIRA, T. S.; FERNANDES, M. J.; CRUZ, A. P. M.; CARVALHO, A. S. R. Substrato, temperatura de germinação e desenvolvimento pósseminal de sementes de Dalbergia nigra. Pesquisa Agropecuária Brasileira, Brasília, v. 41, n. 3, p. 517-523, 2006.

AZERÊDO, G. A.; PAULA, R. C.; VALERI, S. V. Temperatura e substrato para a germinação de sementes de Piptadenia moniliformis Benth. Scientia Forestalis, Piracicaba, v. 39, n. 92, p. 479-488, 2011.

AZERÊDO, G. A.; PAULA, R. C.; VALERI, S. V.; MORO, F. V. Superação de dormência em sementes de Piptadenia moniliformis Benth. Revista Brasileira de Sementes, Londrina, v. 32, n. 2, p. 49-58, 2010.

BELlO, E. P. B. C. S.; ALBUQUERQUE, M. C. F.; GUIMARÃES, S. C.; MENDONÇA, E. A. F. Germinação de sementes de Amburana acreana (Ducke) A. C. Sm. submetidas a diferentes condições de temperatura e de estresse hídrico. Revista Brasileira de Sementes, Londrina, v. 30, n. 3, p. 16-24, 2008.

BENEDITO, C. P.; TORRES, S. B.; RIBEIRO, M. C. C.; NUNES, T. A. Superação da dormência em sementes de catanduva (Piptadenia moniliformis Benth.). Revista Ciência Agronômica, Fortaleza, v. 39, n. 1, p. 90-93, 2008.

BRASIL. Ministério da Agricultura, Pecuária e Abastecimento. Instruções para análise de sementes de espécies florestais. Brasília: MAPA/ACS, 2013. 97 p.

Ministério da Agricultura, Pecuária e Abastecimento. Regras para análise de sementes. Ministério da Agricultura, Pecuária e Abastecimento. Secretaria de Defesa Agropecuária. Brasília: Mapa/ACS, 2009. $395 \mathrm{p}$.

CARVALHO, N. M.; NAKAGAWA, J. Sementes: ciência, tecnologia e produção. 5. ed. Jaboticabal: FUNEP, 2012. $590 \mathrm{p}$.

DUTRA, A. S.; MEDEIROS FILHO, S. Dormência e germinação de sementes de albízia (Albizia lebbeck (L.). Revista Ciência Agronômica, Fortaleza, v. 40, n. 3, p. 427-432, 2009.

FIGLIOLIA, M. B.; AGUIAR, I. B.; SILVA, A. G. Germinação de sementes de três espécies arbóreas brasileiras. Revista Instituto Florestal, Colombo, v. 21, n. 1, p. 107-115, 2009.

GUEDES, R. S.; ALVES, E. U.; GONÇALVES, E. P.; BRAGA JÚNIOR, J. M.; VIANA, J. S.; COLARES, P. N. Q. Substratos e temperaturas para testes de germinação e vigor de sementes de Amburana cearenses (Allemao) A.C. Smith. Revista Árvore, Viçosa, MG, v. 34, n. 1, p. 57-64, 2010. 
LABOURIAU, L. G. A germinação de sementes. Washington: Secretaria Geral da Organização dos Estados Americanos, 1983. 174 p.

LIMA, C. R.; PACHECO, M. V.; BRUNO, R. L. A.; FERRAI, C. S.; BRAGA JÚNIOR, J. M.; BEZERRA, A. $\mathrm{K}$. Temperaturas e substratos na germinação de sementes de Caesalpinia pyramidalis Tul. Revista Brasileira de Sementes, Lavras, v. 33, n. 2, p. 216-222, 2011.

LOPES, J. C.; DIAS, P. C.; MACEDO, C. M. P. Tratamentos para superar a dormência de sementes de Ormosia arborea (Vell.) Harms. Brasil Florestal, n. 80, p. 25-35, 2004.

MAGUIRE, J. D. Speed of germination-aid in selection and evaluation for seedling emergence and vigor. Crop Science, Madison, v. 2, n. 1, p. 176-177, 1962.

MAIA, G. N. Caatinga: árvores e arbustos e suas utilidades. São Paulo: D\&Z Computação, 2004. 413 p.

MARCOS-FILHO, J. Fisiologia de sementes de plantas cultivadas. Londrina: ABRATES, 2015. 660 p.

MARTINS, C. C.; MACHADO, C. G.; NAKAGAWA, J. Temperatura e substrato para o teste de germinação de sementes de barbatimão (Stryphnodendron adstringens (Mart.) Coville (Leguminoseae)). Revista Árvore, Viçosa, MG, v. 32, n. 4, p. 633-639, 2008.

MELO, J. L. O.; BARBEDO, C. J. Temperatura, luz e substrato para germinação de sementes de paubrasil (Caesalpinia echinata Lam.) (Leguminosa Caesalpinioideae). Revista Árvore, Viçosa, MG, v. 31, n. 4, p. 102-112, 2007.

MELO, M. G. G.; MENDONÇA, M. S.; NAZÁRIO, P.; MENDES, A. M. S. Superação de dormência em sementes de três espécies de Parkia spp. Revista Brasileira de Sementes, Londrina, v. 33, n. 3, p. 533-542, 2011.

NASCIMENTO, I. L.; ALVES, E. U.; BRUNO, R. L. A.; GONÇALVES, E. P.; COLARES, P. N. Q.; MEDEIROS, M. S. Superação da dormência em sementes de faveira (Parkia platycephala Benth.). Revista Árvore, Viçosa, MG, v. 33, n. 1, p. 35-45, 2009.

OLIVEIRA, L. M.; BRUNO, R. L. A.; GONÇALVES, E. P.; LIMA JÚNIOR, A. R. Tratamentos pré-germinativos em sementes de Caesalpinia pulcherrima (L.) Sw. LEGUMINOSAE. Revista Caatinga, Mossoró, v. 23, n. 1, p. 71-76, 2010.

PASSOS, M. A.; TAVARES, K. M. P.; ALVES, A. R. Germinação de sementes de sabiá (Mimosa caesalpiniifolia Benth.). Revista Brasileira de Ciências Agrárias, Recife, v. 2, n. 1, p. 51-56, 2007.
SCALON, S. P. Q.; SCALON FILHO, H.; MUSSURY, R. M.; MACEDO, M. C.; KISSMANN, C. Potencial germinativo de sementes de Dimorphandria mollis Benth. em armazenamento, tratamentos pré-germinativos e temperatura de incubação. Cerne, Lavras, v. 13, n. 3, p. 321-328, 2007.

SHIMIZU, E. S. C.; PINHEIRO, H. A.; COSTA, M. A.; SANTOS FILHO, B. G. Aspectos fisiológicos da germinação e da qualidade de Schizolozobiumamazonicum em resposta a escarificação das sementes em lixa e água quente. Revista Árvore, Viçosa, MG, v. 35, n. 4, p. 791800. 2011.

SILVA, A. I. S.; CORTE, V. B.; PEREIRA, M. D.; CUZZUOL, G. R. F.; LEITE, I. T. A. Efeito da temperatura e de tratamentos pré-germinativos na germinação de sementes de Adenanthera pavonina L. Semina: Ciências Agrárias, Londrina, v. 30, n. 4, p. 815-824, 2009.

SMIDERLE, O. J.; MOURÃO JUNIOR, M.; SOUSA, R. C. P. Tratamentos pré-germinativos em sementes de acácia. Revista Brasileira de Sementes, Londrina, v. 27, n. 1, p. 78-85, 2005.

SMIDERLE, O. J.; SCHWENGBER, L. A. M. Superação de dormência em sementes de paricana (Bowdichia virgilioides Kunth.). Revista Brasileira de Sementes, Londrina, v. 33, n. 3, p. 407-414, 2011.

SMIDERLE, O. J.; SOUSA, R. C. P. Seed dormancy of paricarana tree (Bowdichia virgilioides Kunth) Fabaceae - Papilionidae. Revista Brasileira de Sementes, Pelotas, v. 25, n. 2, p. 48-53, 2003.

SOUZA, E. R. B.; ZAGO, R.; GARCIA, J.; FARIAS, J. G.; CARVALHO, E. M. S.; BARROSO, M. R. Efeito de métodos de escarificação do tegumento em sementes de Leucaena diversifolia L. Pesquisa Agropecuária Tropical, Goiânia, v. 37, n. 3, p. 142-146, 2007.

SOUZA, R. S. O.;ALBUQUERQUE, U. P.; MONTERIO, J. M.; AMORIM, E. L. C. Jurema-preta (Mimosa tenuiflora [Willd.] Poir.): a review of its traditional use, phytochemistry and pharmacology. Brazilian Archives of Biology and Technology, Recife, v. 51, n. 5, p. 937-947, 2008.

VIVIAN, R.; SILVA, A. A.; GIMENES JÚNIOR, M.; FAGAN, E. B.; RUIZ, S. T.; LABONIA, V. Dormência em sementes de plantas daninhas como mecanismo de sobrevivência - breve revisão. Planta Daninha, Viçosa, MG, v. 26, n. 3, p. 695-706, 2008. 